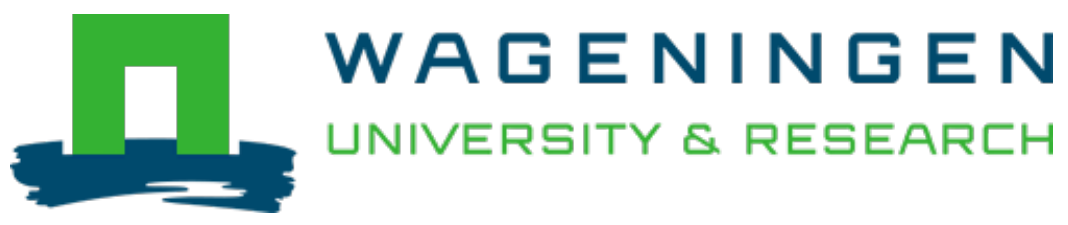

\title{
Effect of processing on the diffusion of alkaloids and quality of lupinus mutabilis sweet
}

\author{
Journal of Food Processing and Preservation \\ Carvajal Larenas, F.E.; Boekel, M.A.J.S.; Koziol, M.; Nout, M.J.R.; Linnemann, A.R. \\ https://doi.org/10.1111/jfpp.12105
}

This publication is made publicly available in the institutional repository of Wageningen University and Research, under the terms of article $25 \mathrm{fa}$ of the Dutch Copyright Act, also known as the Amendment Taverne. This has been done with explicit consent by the author.

Article 25 fa states that the author of a short scientific work funded either wholly or partially by Dutch public funds is entitled to make that work publicly available for no consideration following a reasonable period of time after the work was first published, provided that clear reference is made to the source of the first publication of the work.

This publication is distributed under The Association of Universities in the Netherlands (VSNU) 'Article $25 \mathrm{fa}$ implementation' project. In this project research outputs of researchers employed by Dutch Universities that comply with the legal requirements of Article $25 \mathrm{fa}$ of the Dutch Copyright Act are distributed online and free of cost or other barriers in institutional repositories. Research outputs are distributed six months after their first online publication in the original published version and with proper attribution to the source of the original publication.

You are permitted to download and use the publication for personal purposes. All rights remain with the author(s) and / or copyright owner(s) of this work. Any use of the publication or parts of it other than authorised under article $25 \mathrm{fa}$ of the Dutch Copyright act is prohibited. Wageningen University \& Research and the author(s) of this publication shall not be held responsible or liable for any damages resulting from your (re)use of this publication.

For questions regarding the public availability of this publication please contact openscience.library@wur.nl 


\title{
EFFECT OF PROCESSING ON THE DIFFUSION OF ALKALOIDS AND QUALITY OF LUPINUS MUTABILIS SWEET
}

\author{
F.E. CARVAJAL-LARENAS ${ }^{1}$, M.J.A.S. VAN BOEKEL ${ }^{2}$, M. KOZIOL ${ }^{1}$, M.J.R. NOUT ${ }^{3,4}$ and A.R. LINNEMANN² \\ ${ }^{1}$ Colegio Politécnico. Departamento de Ingeniería en Alimentos, Universidad San Francisco de Quito, Quito, Ecuador \\ 2Product Design and Quality Management Group, Wageningen University, Wageningen, The Netherlands \\ ${ }^{3}$ Laboratory of Food Microbiology, Wageningen University, Bomenweg 2, Wageningen 6703HD, The Netherlands
}

${ }^{4}$ Corresponding author.
TEL: +31 317484339.
FAX: +31 $317484978 ;$
EMAIL: Rob.Nout@wur.nl
Received for Publication October 3, 2012
Accepted for Publication February 12, 2013

doi:10.1111/jfpp.12105

\begin{abstract}
Cold water processing by soaking, cooking and washing has been used for hundreds of years to produce debittered lupine in the Andean region. The process of debittering lupine (Lupinus mutabilis Sweet) was investigated at semi-industrial village-scale and laboratory scale in Ecuador. The process took $5.7 \pm 1.0$ days, removed $94.9 \%$ of the total alkaloids, used water at almost 62 times the weight of the raw dry and bitter lupine, and caused a $22 \%$ loss of total solids, principally fat, minerals and carbohydrates. During the debittering process the microbiological quality deteriorated. Mathematical modeling based on Fickian diffusion suggested that the diffusion coefficient of alkaloids would be expected to be between $10^{-10}$ and $10^{-11} \mathrm{~m}^{2} / \mathrm{s}$ because the lupine endosperm is a polymer matrix whose properties change during processing. Of the process operations, cooking was the most efficient at removing alkaloids both in terms of time and water used, followed by soaking and washing.
\end{abstract}

\section{PRACTICAL APPLICATIONS}

The current debittering process of bitter toxic lupine in San Pedro, Ecuador, is effective but consumes much water and time. During the process, not only alkaloids are removed but also $22 \%$ of total solids, principally fats, minerals and carbohydrates. The microbiological quality of the product deteriorates during this long processing time. Improving the efficiency of the debittering process would reduce water consumption, save time and improve the nutritional and microbiological quality of the final product. Future work will focus on strategies to optimize the debittering process.

\section{INTRODUCTION}

Lupine is a tall-growing grain legume (Pate et al. 1985), which is employed as a protein source in human and animal nutrition (Güémes-Vera et al. 2008). Some lupine species have functional properties in bakery and pastry products (Güémes-Vera et al. 2008), e.g., by increasing water absorption of the dough (Güémes-Vera et al. 2008). The consumption of lupine might have beneficial effects on human health (Güémes-Vera et al. 2008) as they contain antimutagenic, anticarcinogenic, hypocholesterolemic, and antioxidant phenolic compounds, and prebiotic oligosaccharides, which favor the proliferation of bifidobacteria (Jiménez-Martínez et al. 2003b).
The FAO (2009) reported that more than 585,000 metric tons of lupine were produced in 2007, with the legume being cultivated in Germany, Poland, the Russian Federation and Mediterranean countries as well as in Australia, South Africa and South America. Four major crop species are cultivated, namely Lupinus albus L., L. luteus L., L. angustifolius L. and L. mutabilis Sweet, of which the latter is cultivated in Ecuador, Peru and Chile, and which shows the highest average content, on a dry weight basis, of protein $(440 \mathrm{~g} / \mathrm{kg})$ and lipids $(180 \mathrm{~g} / \mathrm{kg})$ (Pate et al. 1985). L. mutabilis is commonly known in Chile as "lupino" (Peralta et al. 2001), in Peru as "tarhui" (Aguilera and Trier 1978; Torres-Tello et al. 1980) or "tarwi" (Aguilera and Trier 1978; Santos et al. 1997; Caicedo et al. 2001) depending on 
the translation from the Quechua, and as "chocho" in Ecuador (Aguilera and Trier 1978; Villacrés et al. 2003).

In Ecuador, lupine can be cultivated in the harsh climates of the Andes and in poor soils. It is an important food crop whose production increased from 662 metric tons in 1986 (Moncayo et al. 2000) to 789 tons in 2000 (Junovich 2003), with up to $90 \%$ of this production destined for human consumption (Aguilera and Trier 1978; Petterson and Crosbie 1990; Gueguen and Cerletti 1994; Zduńczyk et al. 1996; Santos et al. 1997; Caicedo et al. 2001). Its nutritional value is similar to that of soya bean (Aguilera and Trier 1978; Petterson and Crosbie 1990; Gueguen and Cerletti 1994; Zduńczyk et al. 1996; Santos et al. 1997), and therefore the crop is known as the soya bean of the Andes (Villacrés et al. 2003). In spite of its importance, lupine has been studied much less than soya bean (Gueguen and Cerletti 1994). The use of lupine as a protein-rich food crop is hampered by its high alkaloid content (Aguilera and Trier 1978; Aguilera et al. 1983; Petterson and Crosbie 1990), which has a useful function in the lupine plant because it gives high resistance to microbial infections and insect attacks (Ciesiolka et al. 2005). These bitter tasting and toxic components must be removed before consumption (Aguilera and Trier 1978; Aguilera et al. 1983; Beirao da Costa 1989; Petterson and Crosbie 1990; Haq 1993; Gueguen and Cerletti 1994; Zduńczyk et al. 1996). Detoxification was attempted by chemical (Von Baer et al. 1979; Torres-Tello et al. 1980; Ortiz and Mukherjee 1982; Chango et al. 1993; Touche et al. 1997; Nossak et al. 2000; Jiménez-Martínez et al. 2003a) and biological methods (Szakács and Stankovics 1983; Agosin et al. 1989; Camacho et al. 1991; Santana et al. 1996; Santana and Empis 2001). As an extraction solvent, water in combination with several chemicals (Gueguen and Cerletti 1994) or water-alcohol mixtures were tested (Kahnt and Kurz 1989). Water as the only solvent was investigated both at a laboratory (Torres-Tello et al. 1980; Aguilera et al. 1983) and at commercial scale (Rossetto 1989), and was considered (Chajuss 1989) the most economical way to remove alkaloids. The use of water is advantageous because it prevents environmental contamination with chemical products and does not require the recovery of organic solvents (Rossetto 1989).

In the Andean Region the process of debittering lupine with water has been in use since pre-Inca times (Torres-Tello et al. 1980). In Ecuador, the National Agricultural Research Centre (INIAP) has proposed a commercial wet-warm debittering process, which consists of soaking the lupine for $14-16 \mathrm{~h}$ at $40 \mathrm{C}$, boiling for $40 \mathrm{~min}$, and then washing at 40C (Caicedo et al. 2001). The process uses potable water and applies good manufacturing practices (Caicedo et al. 2001). However, limited information is available on the consequences of debittering of lupine with water as regards (1) the amount of water and time used in each stage of the process and in the process as a whole; (2) the alkaloid content in lupine before and after each stage of the debittering process; (3) the changes in the nutritional composition of debittered lupine regarding macro- and micronutrients; (4) the microbiological quality of the lupine before and after debittering; (5) an estimation of the diffusion time of alkaloids in water; and (6) a model of the diffusion of alkaloids in water.

The current investigation was performed to contribute to the knowledge about the wet processing of lupine in cold water and to offer insights to improve the present system to the benefit of processors and consumers of lupine.

\section{MATERIALS AND METHODS}

\section{Field Survey}

The debittering process with cold water is used on both household and commercial scale in the village of San Pedro in the Province of Cotopaxi in Ecuador. In this village, the debittering is performed in approximately 40 small factories, of which 10 were selected and surveyed to define the debittering process in use.

\section{Raw Lupine}

A composite batch of raw bitter lupine ( $15 \mathrm{~kg})$ was obtained by pooling equal quantities obtained from five processors (3 $\mathrm{kg}$ from each) using random sampling in the village of San Pedro, Cotopaxi Province, Ecuador. All the processors used Lupinus mutabilis Sweet. From this batch, a sample of $500 \mathrm{~g}$ was reserved for microbiological determinations that were performed. The remaining $14.5 \mathrm{~kg}$ were stored dry and were used for the debittering experiments and for the determination of macronutrients, iron, zinc and total alkaloid concentrations. All determinations were performed in duplicate.

\section{Sampling}

Samples were taken at 4-h intervals for soaking experiments, at 15-min intervals for cooking effect, for washing effect and materials balance at $12 \mathrm{~h}$ during the first 2 days, followed by $6-\mathrm{h}$ intervals the next day; during the final washing period, samples were evaluated each hour.

For composition and microbiological quality, samples were evaluated at the end of the process.

For analysis of efficiency the amount of water was registered every time it was added. Time was registered at the end of the process, and alkaloids were analyzed during and at the end of the process. 


\section{Debittered Lupine}

For microbiological determinations, debittered lupine was randomly sampled from five processors ( $800 \mathrm{~g}$ from each). The samples were collected in sterile containers and kept refrigerated until analysis.

For the determination of macronutrients, iron, zinc and total alkaloid concentrations, lupine was randomly sampled from the same five processors (500 g from each). All samples were analyzed in duplicate.

\section{Determination of Macronutrients, Iron, Zinc and Microbiological Quality in Raw and Debittered Lupine}

In both raw bitter, and debittered lupine, protein was determined by Association of Official Analytical Chemists (AOAC) method 2001.11 using the default $\mathrm{N}: \mathrm{P}$ conversion factor of 6.25, fat by AOAC 920.39C, ash by AOAC 923.03, moisture content by AOAC 925.09 and carbohydrates, which included fiber, were calculated as the difference (100\% - \%moisture - \%protein - \%fat - \%ash - \%alkaloids). Iron and zinc were determined using AOAC 999.11 method (AOAC 2005).

Total mesophilic aerobic plate count (colony forming units [cfu]) was determined by AOAC method 966.23, fungal plate count by AOAC 997.02 (AOAC 2005) and E. coli (most probable number $[\mathrm{MPN}]$ ) by the method of the Ecuadorean Institute of Standards (Instituto Ecuatoriano de Normalización) (INEN Instituto Ecuatoriano de Normalización 1990).

\section{Determination of Alkaloids}

For the determination of alkaloid concentrations in raw bitter lupine, $1 \mathrm{~kg}$ of the previously pooled sample of $14.5 \mathrm{~kg}$ was milled using a model $4 \mathrm{E}$ mill (The Strub Company, Hatboro, PA) and sieved with a shaking 60 mesh sieve (Meinzer II, Series 0447, Fairfax, VA; dual model, MFG Co. Chicago, IL), with the throughs taken for analysis. The lupine was not dehulled before milling and sieving. All alkaloid determinations were performed in duplicate.

All chemicals were analytical grade obtained from Merck Ecuador, Quito, Ecuador: chloroform (catalog number 1024452500), $\mathrm{Al}_{2} \mathrm{O}_{3}$ (1010671000), Dragendorff's reagent (1020350100) and methyl red indicator (1060760100). A $0.01 \mathrm{M}$ solution of sodium hydroxide was prepared by diluting a standard solution $0.1 \mathrm{M}$ of sodium hydroxide (Merck Ecuador, 109141100) in freshly distilled water. A solution $0.005 \mathrm{M}$ of sulfuric acid was obtained by diluting sulfuric acid 0.05 M (for titration, 1099840001) in freshly distilled water. Potassium hydroxide solution (2.68 M, catalog number 0421) was obtained from AIC Cia. Ltda., Quito, Ecuador.

Alkaloid concentrations were determined by titration using the methodology described by von Baer et al. (1979) with the modification suggested by the Ecuadorean Institute of Standards (INEN Instituto Ecuatoriano de Normalización 2005): this is the current official method in Ecuador. To $0.2 \mathrm{~g}$ lupine ground to pass a 60 mesh screen, $0.6 \mathrm{~g}$ of basic $\mathrm{Al}_{2} \mathrm{O}_{3}$ was added and blended to a fine powder. Then $0.2 \mathrm{~mL}$ of $2.68 \mathrm{M} \mathrm{KOH}$ was added and blended again to a homogeneous paste. This paste was then transferred to centrifuge tubes, and $6 \mathrm{~mL}$ of chloroform was added, followed by mixing with a glass stirring rod and centrifuging for $2 \mathrm{~min}$ at $900 \mathrm{~g}$. The supernatant was poured through a cotton filter into a glass vial. The process of adding chloroform, mixing, centrifuging and filtering was repeated at least 10 times, until absence of alkaloids in the final extract could be demonstrated. This was done by adding four to five drops of $0.005 \mathrm{M}$ sulfuric acid and three to four drops of Dragendorff's reagent to $1 \mathrm{~mL}$ of the final extract: a negative reaction (absence of orange colored spots) should result (Nerín and Garnica 1986). Finally, the funnel used for the filtration was rinsed with $15 \mathrm{~mL}$ of chloroform. All extracts, including the last $15 \mathrm{~mL}$ wash, were collected in the glass vial and were evaporated at $30 \mathrm{C}$ until $1 \mathrm{~mL}$ remained; this was further evaporated when cooling the sample in a $15 \mathrm{C}$ water bath. For the determination of alkaloid concentrations, $5 \mathrm{~mL}$ of $0.005 \mathrm{M}$ sulfuric acid and two drops of methyl red indicator were added to the vial. The excess acid was titrated with $0.01 \mathrm{M} \mathrm{NaOH}$. The concentration of total alkaloids, expressed as lupanine content $(\mathrm{g} / 100 \mathrm{~g})$, was calculated as follows (INEN Instituto Ecuatoriano de Normalización 2005):

$$
\begin{aligned}
& \text { Total alkaloids expressed as lupanine }(\mathrm{g} / \mathrm{l} 00 \mathrm{~g}) \\
& =\frac{0.248 \times \mathrm{V}}{\text { weight of sample }(\mathrm{g})}
\end{aligned}
$$

$\mathrm{V}=\mathrm{V}_{0}-\mathrm{V}_{1}$

$\mathrm{V}_{0}=5 \mathrm{~mL}$

$\mathrm{V}_{\mathrm{l}}=\mathrm{ml}$ used in titration

0.248 represents the weight of lupanine $(\mathrm{g})$ in a solution $0.01 \mathrm{M}(2.48 \mathrm{~g}) \times 100$ (to express the result directly in percentage)/1,000 (transformation of $\mathrm{ml}$ of acid to liters).

\section{Water used in the Debittering Process}

Raw, dehulled lupine was debittered in the laboratory by the same procedure as used by the local processors (Fig. 1 and Table 1, using the maximum time for soaking and boiling and the minimum time for washing), which are conditions similar to those of the procedure proposed by INIAP 


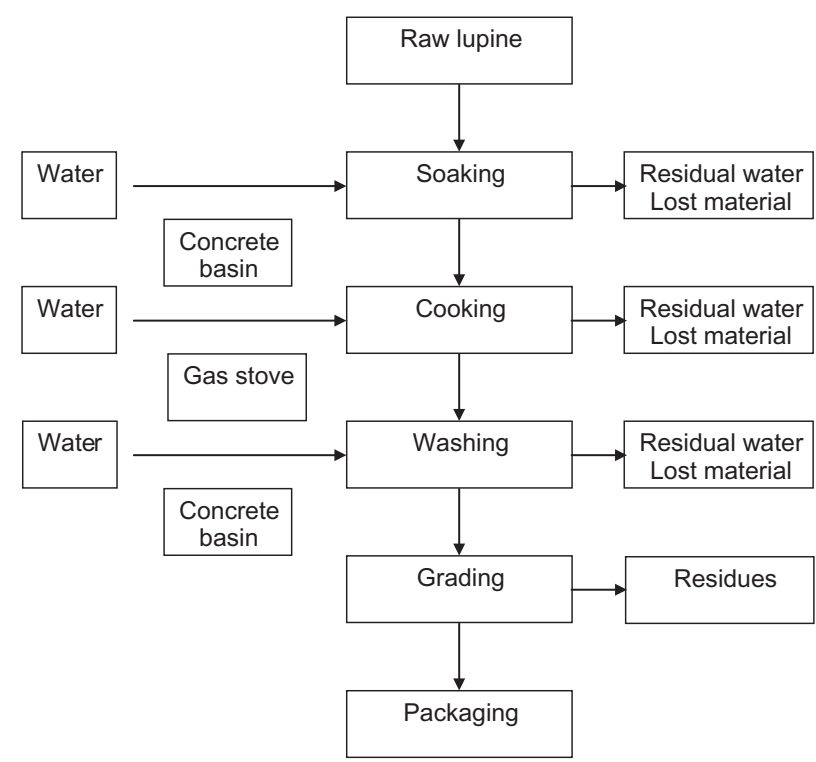

FIG. 1. PROCESS FOR DEBITTERING LUPINE

Performed in the village of San Pedro, Cotopaxi Province, Ecuador.

(Caicedo et al. 2001). Each batch started with 1,000 g of raw, dehulled lupine.

The minimum water: lupine ratio used was $2.5: 1(\mathrm{w} / \mathrm{w})$ for soaking, boiling, and washing of the raw lupine. This amount of water was the minimum needed to keep the lupine covered by water at all times. During the washing process the water was changed three times per day, namely at 9:00 a.m., 12:00 p.m. and 4:00 p.m. The total amount of water used was established as the difference between the water added before each operation and that remaining after the operation.

\section{Efficiency of Each Operation in the Debittering Process}

Total alkaloid concentrations were determined before and after each operation with the methodology described above. This information was combined with that for the water used for debittering and the time required for each operation to estimate the efficiency of each step of the debittering process. The equations used were

$$
\begin{aligned}
& \text { Water efficiency }(\mathrm{g} / \mathrm{kg}) \\
& =\frac{\text { alkaloids extracted }(\mathrm{g} / \mathrm{kg} \text { raw dry lupine })}{\text { water used }(\mathrm{kg} / \mathrm{kg} \text { raw dry lupine })}
\end{aligned}
$$

Where water efficiency is expressed in $\mathrm{g}$ of alkaloids extracted per $\mathrm{kg}$ of water used.

$$
\begin{aligned}
& \text { Time efficiency }(\mathrm{g} / \mathrm{kg} \text { x h) } \\
& =\frac{\text { alkaloids extracted }(\mathrm{g} / \mathrm{kg} \text { raw dry lupine })}{\text { time used }(\mathrm{h})}
\end{aligned}
$$

Where time efficiency is expressed in $\mathrm{g}$ of alkaloids extracted per $\mathrm{kg}$ of raw lupine and hour of extraction.

\section{Estimation of the Diffusion Time of Alkaloids in Water}

To assess possible improvements in efficiency, a theoretical diffusion time for alkaloids in lupine was calculated and compared with that used in the current debittering process. The estimated $D$-value was obtained without stirring or agitation.

The theoretical diffusion time, $t$, was calculated according to Walstra (2003) as follows:

$$
t=\mathrm{x}^{2} / D
$$

Where:

$t=$ time (s) required to travel a distance $x$

$x=$ Distance of diffusion $(\mathrm{m})$

$D=$ Diffusion coefficient $\left(\mathrm{m}^{2} / \mathrm{s}\right)$

The maximum distance $(x)$ that an alkaloid molecule would travel in a hydrated seed of lupine was assumed to be the distance between the geometric center of the seed and the integument, approximately $6.4 \times 10^{-3} \mathrm{~m}$. To estimate the diffusion time of alkaloids in lupine the diffusion coefficient of sucrose in most fruits $(D)$ was used, namely $1 \times 10^{-10} \mathrm{~m}^{2} / \mathrm{s}$ (Walstra 2003).

\section{Diffusion Modeling}

To estimate the kinetics of the removal of alkaloids by boiling, soaking and washing, we modeled based on Fickian diffusion (Van Boekel 2009). However, it must be stressed that the process of extraction of alkaloids is very complex. The primarily solid matrix of lupine seed consists mainly of cell walls, protein and starch, forming a polymer network through which the alkaloids must diffuse to reach the surrounding water. A correction to the diffusion constant is needed due to tortuosity (Walstra 2003), meaning that the diffusing molecules need to travel around obstacles. According to Walstra (2003) this could lead to a correction factor

TABLE 1. TIME USED FOR THE DEBITTERING PROCESS OF LUPINE IN THE VILLAGE OF SAN PEDRO, COTOPAXI PROVINCE, ECUADOR

\begin{tabular}{lllll}
\hline & $\begin{array}{l}\text { Soaking } \\
(\mathrm{h})\end{array}$ & $\begin{array}{l}\text { Cooking } \\
(\mathrm{h})\end{array}$ & $\begin{array}{l}\text { Washing } \\
(\mathrm{d})\end{array}$ & $\begin{array}{l}\text { Total } \\
\text { time }(\mathrm{d})\end{array}$ \\
\hline Average \pm S.D. ${ }^{*}$ & $12 \pm 4.6$ & $0.4 \pm 0.4$ & $5.2 \pm 0.8$ & $5.7 \pm 1.0$ \\
Minimum time & 8.0 & 0.2 & 4.5 & \\
Maximum time & 18.0 & 1.0 & 6.0 & \\
\hline
\end{tabular}

* Values represent means \pm standard deviation $(n=10)$.

The end point for the last step is determined by tasting. The time needed for grading and packing depends on the quantity of lupine. 
of up to 0.4 for the diffusion coefficient. Furthermore, during soaking the seeds will imbibe water, and this absorbed water will cause some swelling. While this may enhance the diffusion process because the molecules can now move in a more aqueous environment, it implies that the diffusion constant will change as the process advances. Finally, there could be a considerable constraint for the molecules to cross the barrier between the seed integument and the water, slowing down the extraction process. We did not attempt to model all these processes together. Rather, we wanted to investigate the degree to which Fickian diffusion can describe the observed phenomena.

The starting point for modeling is the second diffusion law of Fick (Crank 1975):

$$
\frac{\partial c_{s}}{\partial t}=D_{s} \frac{\partial^{2} c_{s}}{\partial x^{2}}
$$

where $c_{\mathrm{s}}$ is the concentration of alkaloids in the seed $(\mathrm{g} / \mathrm{kg}), D_{\mathrm{s}}$ the diffusion constant in $\mathrm{m}^{2} / \mathrm{s}, x$ the distance over which the molecules diffuse, $t$ the time in $s$. The boundary conditions needed to solve this equation are (1) only onedimensional radial diffusion is considered over distance $x$, (2) the alkaloids are homogeneously distributed within the seed at time zero, (3) the surrounding water is free of alkaloids at the start, (4) there is no concentration gradient of alkaloids in the water, and (5) the mass balance at the contact side is described as

$$
K_{s / w} \frac{V_{w}}{A} \frac{\partial c_{s}}{\partial x}=-D_{s} \frac{\partial c_{s}}{\partial x} \text { at } x=L_{\mathrm{s}}
$$

where $K_{\mathrm{s} / \mathrm{w}}$ is the partitioning coefficient describing the partitioning between the seed and the water, $V_{\mathrm{w}}$ is the volume of the water in $\mathrm{m}^{3}, L_{\mathrm{s}}$ the distance in $\mathrm{m}$ and $A$ is the contact area in $\mathrm{m}^{2}$. We considered the case of one lupine seed, with average diameter of $0.0128 \mathrm{~m}$, a contact area for radial diffusion of $25 \times 10^{-6} \mathrm{~m}^{2}$, being present in a volume of $2 \mathrm{~mL}$ of water.

These equations were numerically solved using the software program Athena Visual Studio (http://www. athenavisual.com). Since there is no information about the magnitude of the partitioning coefficient we assumed $K_{\mathrm{s} / \mathrm{w}}=1$ and we simulated various values for $D_{\mathrm{s}}$.

\section{Alternatives of Washing and Optimization of this Process}

In accordance with Eqs. (5) and (6) variations in the alkaloid concentration in the seed depend on several factors, most of which cannot be varied. However, the volume of used water can be changed and the impact of this variation on alkaloids content, solids in the product and amount of water used can be measured as a function of time.
In order to do this, a factorial design $(3 \mathrm{~A} \times 3 \mathrm{~B})+1=9$ treatments +1 reference point was used.

Factor A was "changes of water per day" (Ch) with levels 3,6 and 9. The changes of water were spaced evenly during the day. For example, for level 3 changes of water per day water was changed at 8:00 a.m., 4:00 p.m. and 10:00 p.m.

Factor B was "processing time" ( $t$ ) with levels $t 1$, $t 2$ and $t 3$ days. We express the levels in a generic form because each treatment needed different processing times to achieve a safe level of alkaloids (maximum $0.25 \%$ d.w.). Levels $\mathrm{t} 3$ were taken at the end of the process. Levels $\mathrm{t} 1$ and $\mathrm{t} 2$ were taken at equal intervals.

The nine treatments were as follows: three changes of water, time $1(\mathrm{Ch} 3, \mathrm{t} 1)$; three changes of water, time 2 (Ch3, t2); three changes of water, time 3 (Ch3, t3); six changes of water, time 1 (Ch6, t1); six changes of water, time 2 (Ch6, $\mathrm{t} 2$ ); six changes of water, time 3 (Ch6, t3); nine changes of water, time $1(\mathrm{Ch} 9, \mathrm{t} 1)$; nine changes of water, time 2 (Ch9, $\mathrm{t} 2)$; and nine changes of water, time $3(\mathrm{Ch} 9, \mathrm{t} 3)$. The reference point is the lupine before washing $(\mathrm{Ch} 0, \mathrm{t} 0)$. Variables measured were alkaloids content (\% d.w.), water used ( $1 / \mathrm{kg}$ d.w. raw lupine) and solids in the product $(\mathrm{kg} / \mathrm{kg}$ d.w. raw lupine).

The results were analyzed by using the software program Design-Expert 8 (Stat-Ease, Inc., Minneapolis, MN; response surface approach) aiming at an optimum solution (minimization of processing time, water used and maximization of solids in the product) and keeping the alkaloids content at safe level (maximum $0.25 \%$ d.w.).

\section{Statistical Analysis}

Of each sampling point, 3, 5, 6 or even 10 samples were taken. Each sample was analyzed in duplicate.

The Mann-Whitney $U$-test, a nonparametric test, was used to assess differences between two distributions representing raw and debittered lupine. For this purpose, the software package GRAPH PAD INSTAT T.M. V2.01. was used (copyright 1990-1993, Steve Whetzel, Parke-Davis 930762 A; GraphPad Software Inc., San Diego, CA).

\section{RESULTS AND DISCUSSION}

In the village of San Pedro in the Province of Cotopaxi in Ecuador, lupine was debittered with cold water (16C) according to the procedure shown in Fig. 1, which required on average $5.7 \pm 1.0$ days (Table 1 ). The end point of the debittering process was determined by tasting. Local processors complain that this process uses too much water, namely 63 tons of water per ton of raw lupine (Caicedo et al. 2001), and too much time. 
TABLE 2. COMPOSITION OF RAW AND DEBITTERED LUPINE COLLECTED FROM THE VILLAGE OF SAN PEDRO, COTOPAXI PROVINCE, ECUADOR

\begin{tabular}{lccl}
\hline Component & Raw lupine & Debittered lupine & $\mathrm{P}$ value \\
\hline Protein* & $41.4 \pm 0.08 \dagger$ & $55.9 \pm 2.56 \neq$ & $\mathrm{P}<0.05 \S$ \\
Fat* $^{*}$ & $23.4 \pm 0.42$ & $8.9 \pm 2.57$ & $\mathrm{P}<0.05$ \\
Carbohydrates* & $26.6 \pm 0.21$ & $33.1 \pm 2.50$ & $\mathrm{P}<0.05$ \\
Ash* & $5.0 \pm 0.07$ & $1.9 \pm 0.11$ & $\mathrm{P}<0.05$ \\
Alkaloids* & $3.6 \pm 0.07$ & $0.2 \pm 0.01$ & $\mathrm{P}<0.0005$ \\
Iron Zincף & $5.0 \pm 0.43$ & $5.8 \pm 0.61$ & $\mathrm{NS}$ \\
\hline
\end{tabular}

* g/100g dry matter.

+ Values represent means \pm standard deviation $(n=6)$.

₹ Values represent means \pm standard deviation $(n=5)$.

$\S$ Mann-Whitney -U-test; NS = not significant.

If $\mathrm{mg} / 100 \mathrm{~g}$ dry matter.

TABLE 3. MICROBIOLOGICAL QUALITY OF RAW AND DEBITTERED LUPINE COLLECTED FROM THE VILLAGE OF SAN PEDRO, COTOPAXI PROVINCE, ECUADOR

\begin{tabular}{|c|c|c|c|}
\hline Parameter & $\begin{array}{l}\text { Raw } \\
\text { lupine* }\end{array}$ & $\begin{array}{l}\text { Debittered } \\
\text { Lupinet }\end{array}$ & $P$ value $\neq$ \\
\hline $\begin{array}{c}\text { Total mesophilic aerobic } \\
\text { bacteria (Log cfu§/g) }\end{array}$ & 2.67 & 6.71 & $P<0.05$ \\
\hline $\begin{array}{l}\text { Fungi (yeasts and molds) (Log } \\
\text { cfu/g) }\end{array}$ & 2.59 & 1.99 & $P<0.05$ \\
\hline E. coli (presence/g) & Present & Present & \\
\hline
\end{tabular}

* Values represent means $(n=5)$.

+ Values represent means $(n=5)$.

₹ Mann-Whitney -U-test.

$\S c f u / g=$ colony-forming units per gram fresh weight.

Processing the lupine for 5.7 days leads to desirable as well as undesirable changes in composition and microbiological quality as shown in Tables $2-4$. A comparison of the proximate analyses of raw and debittered lupine based on dry weight as presented in Tables 2 and 4 would seem contradictory. For example, carbohydrates increase in Table 2 but decrease in Table 4. The reason is the important loss of solids taking place during the debittering process. Due to losses of dry matter as specified in Table 4, apparent increases of certain components in the dry matter are revealed. In fact, if the amount of carbohydrate in Table 4 (257.9 g dm: dry matter) is expressed on the basis of the total dry matter $(780 \mathrm{~g})$, we obtain the value of $33.1 \mathrm{~g} / 100 \mathrm{~g}$ $\mathrm{dm}$ as in Table 2.

We presented data on the formats of Tables 2 and 4 to point out errors that can be committed when reporting and discussing results of a process where losses of materials take place, without taking these into account. From here onward, our analysis regarding to composition was referred to values reported in Table 4.
Ash (mineral) and alkaloid concentrations were decreased significantly as would be expected from leaching, but interestingly fat concentrations also decreased significantly. Aguilera et al. (1983) reported reductions in fat content in debittered lupine ranging from $50.2 \%$ to $81.6 \%$, similar to our observation (Table 4). Aqueous extraction of fat is most likely due to some sort of micelle formation with the lecithin present in lupine (Rozan et al. 1997).

In debittered lupine, numbers of total mesophilic aerobes were greatly increased (Table 3 ) to levels exceeding the Ecuadorean Sanitary Norm (INEN Instituto Ecuatoriano de Normalización 2005), which stipulates a maximum total plate count of $\log 3 \mathrm{cfu} / \mathrm{g}$ and the absence of E. coli in one gram or $\mathrm{ml}$ of sample. As an extreme case, Villacrés et al. (2000) reported total plate counts of the order of $\log 8 \mathrm{cfu} / \mathrm{g}$ and the occurrence of $E$. coli at levels ranging between $<\log$ 1.48 and $>\log 3.38 \mathrm{cfu} / \mathrm{g}$, estimated by MPN method. As most of this product is consumed without any further processing, it must represent a potential hazard for human consumption.

A general mass balance for the process showed that the amount of water used is about 62 times the weight of raw dry bitter lupine (Fig. 2), confirming observations by Caicedo et al. (2001); the quantity of debittered lupine obtained before grading is 2.8 times that of raw dry lupine, a value similar to the factor reported by Caicedo et al. (2001), namely 2.7 when reported on a dry weight basis. Even though the final weight of the debittered lupine is 2.8 times that of the raw dry material, the process is losing $22 \%$ of initial solids (Fig. 2), a value similar to the $26.9 \%$ loss reported by Torres-Tello et al. (1980). This represents a considerable loss. Based on percentages, the principal components lost during debittering are alkaloids (94.9\%), ash (minerals) and fat (70.3\% each), and carbohydrates $(2.9 \%)$ (Table 4 ). Of the micronutrients, $20.8 \%$ of the zinc and $9.8 \%$ of the iron concentration are lost (Table 4 ).

The debittering process using cold water removed $94.9 \%$ of the total alkaloids (Table 4), compared with 79 to $99.9 \%$

TABLE 4. DRY MATTER BALANCE OF NUTRIENTS AND ALKALOIDS DURING THE DEBITTERING OF RAW LUPINE

\begin{tabular}{lllll}
\hline Material & Raw & Debittered & \multicolumn{1}{l}{ gifference } & $\begin{array}{l}\text { Difference } \\
\%\end{array}$ \\
\hline $\begin{array}{l}\text { Dry Matter (g) } \\
\text { Nutrients: }\end{array}$ & $\mathbf{1 , 0 0 0}$ & $\mathbf{7 8 0 . 0}$ & $\mathbf{- 2 2 0 . 0}$ & $\mathbf{- 2 2 . 0}$ \\
Protein (g) & 414.1 & 435.8 & 21.7 & 5.2 \\
Carbohydrates (g) & 265.6 & 257.9 & -7.7 & -2.9 \\
Fat (g) & 234.2 & 69.5 & -164.7 & -70.3 \\
Ash (g) & 50.5 & 15.0 & -35.5 & -70.3 \\
Iron (mg) & 50.2 & 45.3 & -4.9 & -9.8 \\
Zinc (mg) & 36.0 & 28.5 & -7.5 & -20.8 \\
Total alkaloids (g) & $\mathbf{3 5 . 6}$ & $\mathbf{1 . 8}$ & $\mathbf{- 3 3 . 8}$ & -94.9 \\
\hline
\end{tabular}




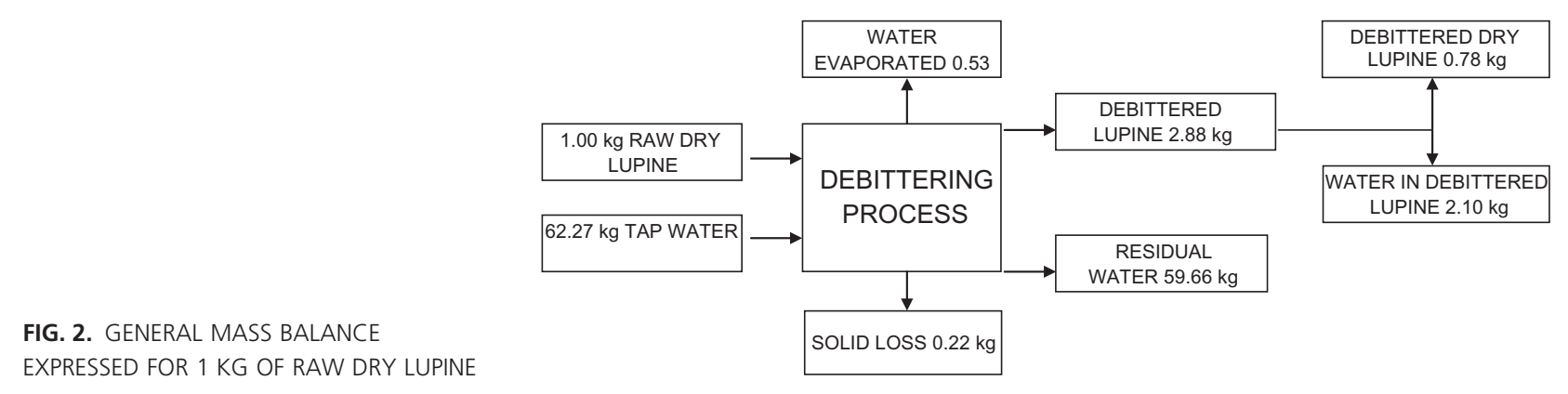

removal achieved by chemical methods (Torres-Tello et al. 1980; Ortiz and Mukherjee 1982; Chango et al. 1993; Jiménez-Martínez et al. 2003a), 14.9 to $99 \%$ by biological methods (Szakács and Stankovics 1983; Agosin et al. 1989; Camacho et al. 1991; Santana et al. 1996; Santana and Empis 2001; Santana et al. 2002), $99.9 \%$ by water-chemical extraction (Aguilera et al. 1983) and $97.7 \%$ by warm water extraction (Caicedo et al. 2001). This indicates that the use of cold water for debittering lupine can achieve a similar detoxification performance as chemical, biological, warm water and combined forms of alkaloids extraction. This traditional process therefore merits an environmentally friendly upgrading in terms of saving water and time.

\section{Debittering Efficiency of Individual Operations of the Debittering Process}

The individual operations in the debittering process show varying degrees of efficiencies regarding the extraction of alkaloids (Table 5). Soaking removed only a small fraction of the total alkaloids and had a low efficiency both in terms of time and the quantity of water used. Despite the fact that the washing operation removed most of the alkaloids, it had a very low efficiency in terms of time and the quantity of water used. The cooking operation had the highest

TABLE 5. DEBITTERING EFFICIENCY OF INDIVIDUAL OPERATIONS IN EXTRACTING ALKALOIDS FROM LUPINE RELATED TO WATER AND TIME USE ( $\mathrm{N}=3$; LABORATORY SCALE EXPERIMENTS)

\begin{tabular}{lcccc}
\hline & \multicolumn{3}{c}{ Operation } & \\
\cline { 2 - 4 } & Soaking & Cooking & Washing & Total \\
\hline $\begin{array}{l}\text { Total alkaloids extracted } \\
\quad \text { (g/100g dry matter) }\end{array}$ & 0.2 & 1.1 & 2.1 & 3.4 \\
$\%$ of total alkaloids extracted & 5.6 & 30.7 & 58.6 & 94.9 \\
Water used (kg/kg raw dry & 2.9 & 2.9 & 56.5 & 62.3 \\
$\quad$ lupine) & & & & \\
Time used (h) & 18.0 & 1.0 & 118.3 & 137.3 \\
Water efficiency* & 0.69 & 3.79 & 0.37 & 0.55 \\
Time efficiency $\dagger$ & 0.11 & 11.00 & 0.18 & 0.25 \\
\hline
\end{tabular}

* Alkaloids extracted (g/kg-water).

† Alkaloids extracted (g/kg-raw-dry lupine/h). efficiency when compared with soaking and washing, as well as with the complete process.

Soaking and cooking are important in the hydration of the integument, endosperm and embryo, and thus have a direct impact on the rate of diffusion of alkaloids from the seed. Thus, $1 \mathrm{~h}$ of cooking removed $30.7 \%$ of the alkaloids, whereas the washing step, conducted at an ambient water temperature of $15 \mathrm{C}$, required $118.3 \mathrm{~h}$ to remove $58.6 \%$ of the alkaloids. This implies that the efficiency of the extraction of alkaloids can be improved by changing the conditions of the debittering process. Although the current process takes 5.7 days, the calculation of a theoretical diffusion for alkaloids based on the diffusion of sucrose in fruits (Walstra 2003) suggests that this could be reduced to 4.8 days as explained below.

Figure 3 shows the strong effect of the magnitude of the apparent diffusion coefficient on extraction. The diffusion coefficient of an alkaloid molecule in water is expected to be around $10^{-10} \mathrm{~m}^{2} / \mathrm{s}$ (Walstra 2003), which is represented in Fig. 3A. However, a lupine seed is not an aqueous environment and consequently the diffusion coefficient would be expected to be lower than $10^{-10} \mathrm{~m}^{2} / \mathrm{s}$. On the other hand, the practical situation resulting in adequate detoxification in 5.7 days, strongly suggests a higher value than $10^{-11} \mathrm{~m}^{2} / \mathrm{s}$ as illustrated in Fig. 3B. Thus, the mathematic model suggests an apparent diffusion coefficient between $1 \times 10^{-10}$ and $1 \times 10^{-11} \mathrm{~m}^{2} / \mathrm{s}$. Indeed, when we substitute in equation (4) $t$ with $492,480 \mathrm{~s}$ (experimental debittering time of 5.7 days) maintaining the distance of diffusion $\left(6.4 \times 10^{-3} \mathrm{~m}\right)$, we obtain an estimated alkaloids diffusion coefficient of approximately $8.32 \times 10^{-11} \mathrm{~m}^{2} / \mathrm{s}$. Obviously, this value is based on the outcome of the total process. During the debittering of the seed, it is hydrated, then cooked and finally washed under different conditions and consequently the diffusion coefficient is expected to vary between and within process operations.

\section{Alternatives of Washing and Optimization of This Process}

The impact of changes of water on alkaloids content, water used and solids in the product throughout time can be 

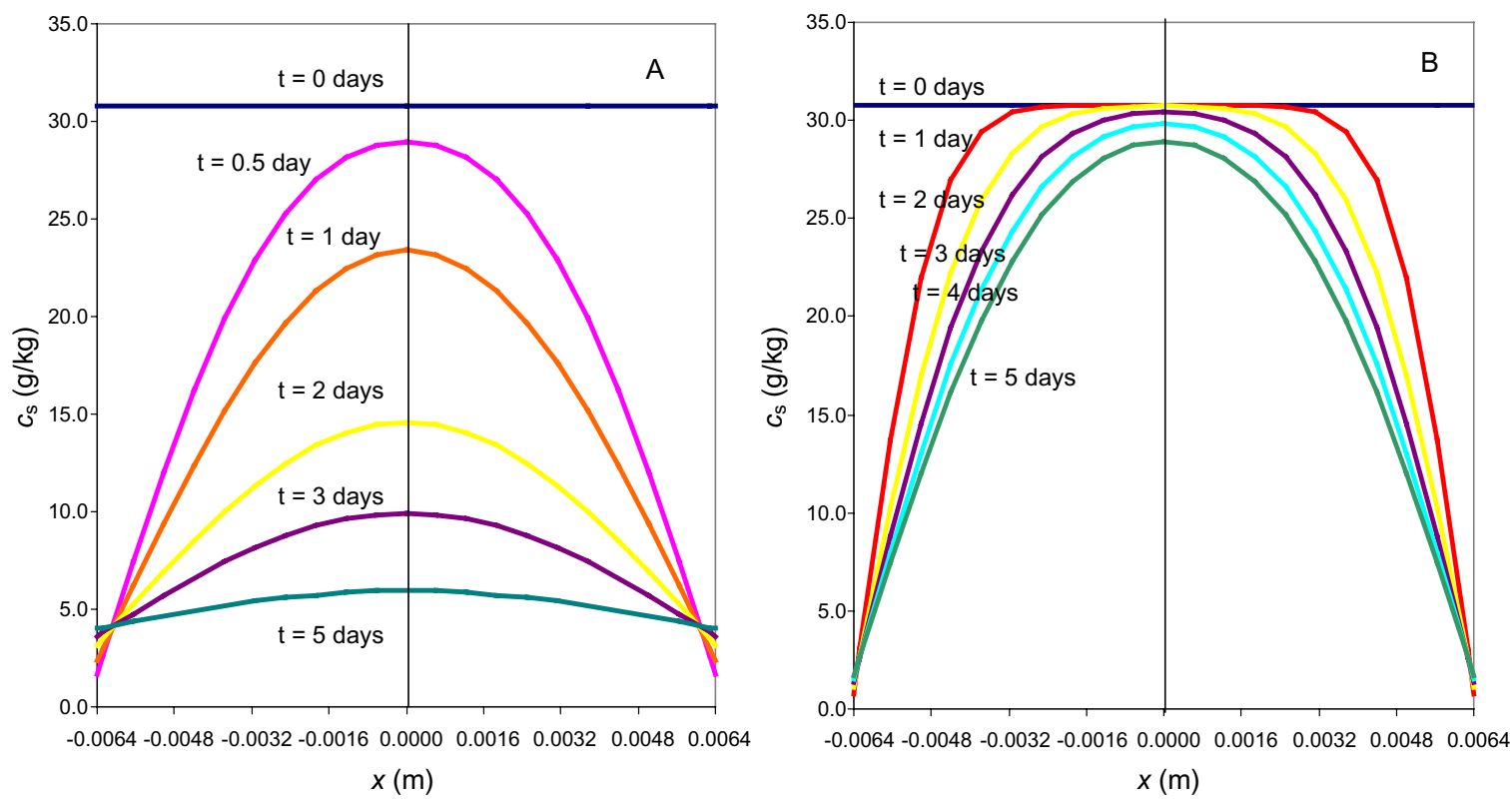

FIG. 3. SIMULATION OF EXTRACTION ACCORDING TO FICKIAN DIFFUSION OF ALKALOIDS IN A LUPINE SEED

Distance $x=0.0128 \mathrm{~m}$, contact area $A=2.5 \times 10^{-5} \mathrm{~m}^{2}, V_{\mathrm{w}}=2 \mathrm{~mL}$, initial concentration $c_{\mathrm{s}}=30.8 \mathrm{~g}$ alkaloid $/ \mathrm{kg}$ lupine, $D_{\mathrm{s}}=1 \times 10^{-10} \mathrm{~m}^{2} / \mathrm{s}(A)$ and $D_{\mathrm{s}}=1 \times 10^{-11} \mathrm{~m}^{2} / \mathrm{s}(\mathrm{B})$.

observed in Table 6. Increasing the number of changes of water/day diminished the time needed to debitter lupine and the solids in the product. However, as it was expected that augmented the amount of water used. The reduction of processing time by increasing the changes of water agrees with Fickian diffusion Eqs. (5) and (6).

Figure 4 shows that lupine can be debittered under different conditions. As an example, we registered two extreme solutions. Unfortunately, the optimization study showed that it is not possible to reduce the water used and the processing duration at the same time with this approach (Fig. 4).

It would be of interest to look for ways to accelerate diffusion, for which several options could be considered either singly or in combination. First, an increase in temperature and its convection effect would seem to be one of the options, but this effect has to be balanced against energy costs and possible other effects on lupine quality, such as an

TABLE 6. TREATMENTS TESTED TO OPTIMIZE THE DEBITTERING PROCESS OF LUPINE $(\mathrm{N}=2)$

\begin{tabular}{|c|c|c|c|c|c|}
\hline \multirow{3}{*}{$\begin{array}{l}\text { Treatment } \\
\text { code* }\end{array}$} & \multicolumn{2}{|l|}{ Factors } & \multicolumn{3}{|l|}{ Variables } \\
\hline & $\begin{array}{l}\text { Changes of } \\
\text { water }\end{array}$ & $\begin{array}{l}\text { Time of } \\
\text { processing }\end{array}$ & Alkaloids & Water used & Solids in product \\
\hline & Times/day & Days & $\%$ d.w. & I/kg d.w. raw lupine & $\mathrm{kg} / \mathrm{kg}$ d.w. raw lupine \\
\hline Chotot & 0 & 0 & $1.74 \pm 0.20$ & $0.00 \pm 0.00$ & $0.90 \pm 0.02$ \\
\hline Ch3t1 & 3 & 1.92 & $1.72 \pm 0.20$ & $21.31 \pm 0.01$ & $0.88 \pm 0.00$ \\
\hline $\mathrm{Ch} 3 \mathrm{t} 2$ & 3 & 3.92 & $0.55 \pm 0.05$ & $42.62 \pm 0.02$ & $0.87 \pm 0.01$ \\
\hline Ch3t3 & 3 & 6.25 & $0.25 \pm 0.00$ & $67.48 \pm 0.04$ & $0.86 \pm 0.03$ \\
\hline Ch6t1 & 6 & 1.97 & $1.27 \pm 0.03$ & $42.28 \pm 0.07$ & $0.82 \pm 0.01$ \\
\hline Ch6t2 & 6 & 3.97 & $0.26 \pm 0.00$ & $84.57 \pm 0.14$ & $0.81 \pm 0.01$ \\
\hline Ch6t3 & 6 & 4.47 & $0.24 \pm 0.00$ & $95.16 \pm 0.14$ & $0.82 \pm 0.02$ \\
\hline Ch9t1 & 9 & 1.95 & $0.50 \pm 0.05$ & $63.92 \pm 0.00$ & $0.80 \pm 0.01$ \\
\hline Ch9t2 & 9 & 2.95 & $0.27 \pm 0.00$ & $95.91 \pm 0.00$ & $0.79 \pm 0.01$ \\
\hline Ch9t3 & 9 & 3.95 & $0.24 \pm 0.00$ & $124.3 \pm 0.00$ & $0.79 \pm 0.01$ \\
\hline
\end{tabular}

* Treatments were ran at random.

† Starting point (reference). 
FIG. 4. GRAPHICAL OPTIMIZATION* OF THE WASHING PROCESS WITH THE FOLLOWING RESTRICTIONS: ALKALOIDS $0.20<X<0.25 \%$ D.W., WATER USED $50<X<100$ L/KG D.W. RAW LUPINE, SOLIDS IN PRODUCT > $0.8 \mathrm{KG} / \mathrm{KG}$ D.W. RAW LUPINE

*Design-Expert 8-Response surface: Quadratic model; no aliases found; average leverage 0.3 ; fraction of design space (FDS)

statistic $=1$ or $100 \%$.

ANOVA response for alkaloids (2FI model, $\left.P<0.0001, r^{2}=0.85\right)$. ANOVA response for water use (quadratic model, $P<0.0001$, $\left.r^{2}=1.00\right)$. ANOVA response for solids in product (quadratic model, $P<0.0001$, $\left.r^{2}=0.93\right)$.

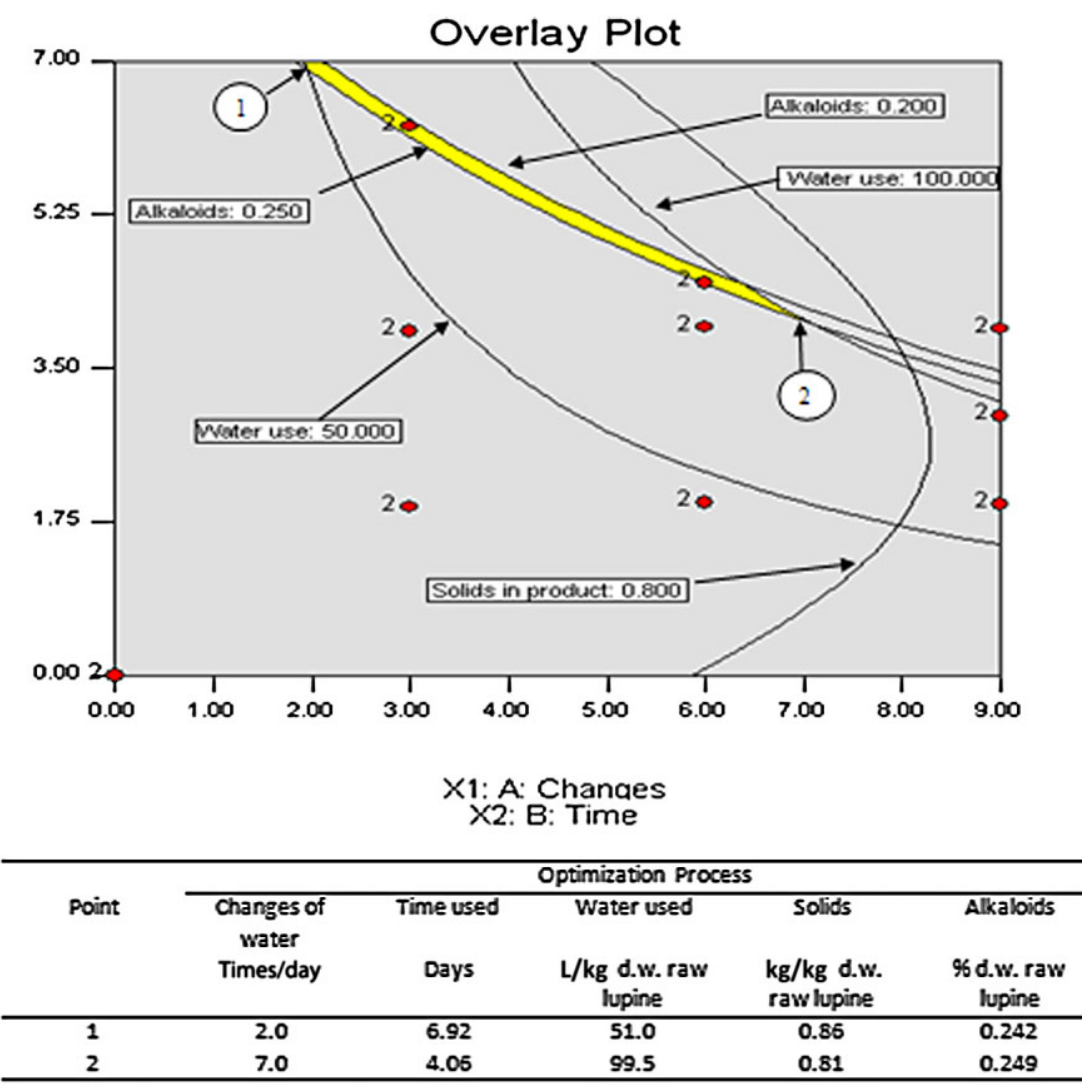

increased leaching of nutrients or microbial growth. Another option would be to attempt to decrease the tortuosity, for example by modifying the soaking process. Reduced tortuosity might be accomplished by soaking lupine in salt solutions. In black beans, soaking in salt solutions has been postulated to increase protein solubility, reduce interactions between minerals and pectin, and to result in a more porous microstructure, thus facilitating water penetration (Sievwright and Shipe 1986). Finally, a continuous replenishment of water in the washing operation might accelerate the diffusion of alkaloids.

\section{CONCLUSION}

The current debittering process of lupine in San Pedro, Ecuador, is effective but consumes much water and time. During the process, not only alkaloids are removed but also $22 \%$ of total solids, principally fats, minerals and carbohydrates. The microbiological quality of the product deteriorates during this long processing time. Improving the efficiency of the debittering process would reduce water consumption, save time and improve the nutritional and microbiological quality of the final product. Future work will focus on strategies to optimize the debittering process.

\section{ACKNOWLEDGMENTS}

The authors gratefully acknowledge the processors of lupine in the village of San Pedro, Cotopaxi Province, Ecuador, for sharing information concerning the debittering process used locally.

This research was conducted in the context of the TELFUN project, supported by the INREF fund (Wageningen University, The Netherlands) and Universidad San Francisco de Quito, Ecuador.

\section{REFERENCES}

AGOSIN, E., DIAZ, D., ARAVENA, R. and YAÑEZ, E. 1989. Chemical and nutritional characterization of lupine tempeh. J. Food Sci. 54, 102-104, 107. AGUILERA, J.M., GERNGROSS, M.F. and LUSAS, E.W. 1983. Aqueous processing of lupin seed. J. Food Technol. 18, 327-333.

AGUILERA, J.M. and TRIER, A. 1978. The revival of the lupin.

J. Food Technol. August, 70-76.

AOAC 2005. Official Methods of Analysis of AOAC International, 18th Ed., Association of Official Analytical Chemists International, Gaithersburg, MD. 
BEIRAO DA COSTA, M.L.D.M. 1989. Aspects of lupin composition as food. In Lupin Production and Bioprocessing for Feed, Food and Other by-Products (Y. Birk, A. Dovrat, M. Waldman and C. Uzureau, eds.) pp. 94-105, National Council for Research and Development, Jerusalem, Israel. CAICEDO, C., PERALTA, E., VILLACRÉS, E. and RIVERA, M. 2001. Poscosecha y mercado del chocho (Lupinus mutabilis Sweet) en Ecuador. Publicación Miscelanea, 105. INIAPFUNDACIT, Quito, Ecuador. In Chocho o lupino producción, fitonutrición, enfermedades y plagas, zonificación, mercado $y$ postcosecha, agroindustria, guía del cultivo de chocho y costos de producción, (E. Peralta, ed.), Published as CD by INIAP-FUNDACIT, Quito, Ecuador, 33 pp.

CAMACHO, L., SIERRA, C., MARCUS, D., GUZMAN, E., CAMPOS, R., VON BAER, D. and TRUGO, L. 1991.

Nutritional quality of lupine (Lupinus albus cv. Multolupa) as affected by lactic acid fermentation. Int. J. Food Microbiol. 14, 277-286.

CHAJUSS, D. 1989. Some technological aspects of lupin versus soybean processing. In Lupin Production and Bioprocessing for Feed, Food and Other by-Products (Y. Birk, A. Dovrat, M. Waldman and C. Uzureau, eds.) pp. 106-114, National Council for Research and Development, Jerusalem, Israel.

CHANGO, A., VILLAUME, C., BAU, H.M., NICOLAS, J.P. and MEJEAN, L. 1993. Debittering of lupin (Lupinus luteus L) protein by calcium alginate and nutritional evaluation. J. Sci. Food Agric. 63, 195-200.

CIESIOLKA, D., GULEWICZ, P., MARINEZ-VILLALUENGA, C., PILARSKI, R., BEDNARCZYK, M. and GULEWICZ, K. 2005. Products and biopreparations from alkaloid-rich lupin in animal nutrition and ecological agriculture. Fol. Biol. (Kraków) 53, 59-66.

CRANK, J. 1975. The Mathematics of Diffusion, Oxford University Press, Oxford, U.K.

FAO 2009. FAO statistical databases. FAO/United Nations,

Rome. http://faostat.fao.org (accessed April 11, 2009).

GUEGUEN, J. and CERLETTI, P. 1994. Proteins of some legume seeds: soybean, pea, fababean and lupin. In New and Developing Sources of Food Proteins (B.J.F. Hudson, ed.) pp. 145-193, Chapman \& Hall, London.

GÜÉMES-VERA, N., PEÑA-BAUTISTA, R.J., JIMÉNEZ-MARTINEZ, C., DÁVILA-ORTIZ, G. and CALDERÓN-DOMÍNGUEZ, G. 2008. Effective detoxification and decoloration of Lupinus mutabilis seed derivatives, and effect of these derivatives on bread quality and acceptance. J. Sci. Food Agric. 88, 1135-1143.

HAQ, N. 1993. Lupins (Lupinus species). In Pulses and Vegetables (J.T. Williams, ed.) pp. 103-129, Chapman \& Hall, London.

INEN INSTITUTO ECUATORIANO DE NORMALIZACIÓN 1990. Norma Técnica Ecuatoriana Obligatoria INEN 1 529-8. Control Microbiológico de los Alimentos. Determinación de Coliformes Fecales y E. coli, pp. 1-9, Instituto Ecuatoriano de Normalización, Quito, Ecuador.
INEN INSTITUTO ECUATORIANO DE NORMALIZACIÓN 2005. Leguminosas. Grano amargo de chocho. Requisitos. pp. 1-10. Instituto Ecuatoriano de Normalización.

JIMÉNEZ-MARTÍNEZ, C., HERNÁNDEZ-SÁNCHEZ, H. and DÁVILA-ORTIZ, G. 2003a. Lupines: an alternative for debittering and utilization in foods. In Food Science and Food Biotechnology (G. Gutiérrez-López and G. Barbosa-Canovas, eds.) pp. 233-252, Food Preservation Technology Series. CRC Press, Boca Raton, FL.

JIMÉNEZ-MARTÍNEZ, C., LOARCA-PIÑA, G. and DÁVILA-ORTÍZ, G. 2003b. Antimutagenic activity of phenolic compounds, oligosaccharides and quinolizidinic alkaloids from Lupinus campestris seeds. Food Addit. Contam. 20, 940-948.

JUNOVICH, A. 2003. El cultivo del chocho a través de los datos del III Censo Nacional Agropecuario. Proyecto SICA, Banco Mundial. pp. 1-6. Ministerio Industrias, Comercio, Integración y Pesca del Ecuador and Banco Mundial, Quito, Ecuador.

KAHNT, G. and KURZ, C. 1989. Some possibilities realizing the genetic yield potential of lupins. In Lupin Production and Bio-Processing for Feed, Food and Other by-Products (Y. Birk, A. Dovrat, M. Waldman and C. Uzureau, eds.) pp. 32-47, National Council for Research and Development, Jerusalem, Israel.

MONCAYO, L., BARRERA, V., CAICEDO, C., PERALTA, E. and RIVERA, M. 2000. Sistemas de producción de chocho en la sierra Ecuatoriana. In Zonificación Potencial, Sistemas de Producción y Procesamiento Artesanal del Chocho (Lupinus mutabilis Sweed) en Ecuador (C. Caicedo and E. Peralta, eds.) pp. 9-23, Programa Nacional de Leguminosas, Boletín Técnico. INIAP-FUNDACIT, Quito, Ecuador. In Chocho o lupino producción, fitonutrición, enfermedades y plagas, zonificación, mercado y postcosecha, agroindustria, guía del cultivo de chocho y costos de producción, (E. Peralta, ed.) Published as CD by INIAP-FUNDACIT, Quito, Ecuador, Quito, Ecuador.

NERÍN, C. and GARNICA, A. 1986. Indirect determination of nitrogenated drugs by atomic absorption spectrometry. Anal. Chem. 58, 2617-2621.

NOSSAK, A.C., VILEGAS, J.H.Y., VON BAER, D. and LANÇAS, F.M. 2000. Supercritical fluid extraction and chromatographic analysis (HRGC-FID and HRGC-MS) of Lupinus spp. alkaloids. J. Brazil Chem. Soc. 11, 495-501.

ORTIZ, J.G.F. and MUKHERJEE, K.D. 1982. Extraction of alkaloids and oil from bitter lupin seed. J. Am. Oil Chem. Soc. 59, 241-244.

PATE, J.S., WILLIAM, W. and FARRINGTON, P. 1985. Lupin (Lupinus spp.). In Grain Legume Crops (R.J. Summerfield and E.H. Roberts, eds.) pp. 699-746, Collins Professional and Technical Books, London.

PERALTA, E., MAZÓN, N. and VILLACRÉS, E. 2001. Chocho congelado. INIAP-FUNDACIT, Quito, Ecuador. In Chocho o lupino producción, fitonutrición, enfermedades y plagas, zonificación, mercado y postcosecha, agroindustria, guía del 
cultivo de chocho y costos de producción, (E. Peralta, ed.) Published as CD by INIAP-FUNDACIT, Quito, Ecuador, 5 pp. PETTERSON, D.S. and CROSBIE, G.B. 1990. Potential for lupins as food for humans. Food Aust. 42, 266-268.

ROSSETTO, G. 1989. Lupin production and processing study. In Lupin Production and Bioprocessing for Feed, Food and Other by-Products (Y. Birk, A. Dovrat, M. Waldman and C. Uzureau, eds.) pp. 70-75, National Council for Research and Development, Jerusalem, Israel.

ROZAN, P., LAMGHARI, R., LINDER, M., VILLAUME, C., FANNI, J., PARMENTIER, M. and MEJEAN, L. 1997. In vivo and in vitro digestibility of soybean, lupine, and rapeseed meal proteins after various technological processes. J. Agric. Food Chem. 45, 1762-1769.

SANTANA, F.C. and EMPIS, J. 2001. Bacterial removal of quinolizidine alkaloids from Lupinus albus flours. Eur. Food Res. Technol. 212, 217-224.

SANTANA, F.M.C., FIALHO, A.M., SÁ-CORREIA, I. and EMPIS, J.M.A. 1996. Isolation of bacterial strains capable of using lupanine, the predominant quinolizidine alkaloid in white lupin, as sole carbon and energy source. J. Ind. Microbiol. 17, 110-115.

SANTANA, F.M.C., PINTO, T., FIALHO, A.M., SÁ-CORREIA, I. and EMPIS, J.M.A. 2002. Bacterial removal of quinolizidine alkaloids and other carbon sources from a Lupinus albus aqueous extract. J. Agric. Food Chem. 50, 2318-2323.

SANTOS, C.N., FERREIRA, R.B. and TEIXEIRA, A.R. 1997. Seed proteins of Lupinus mutabilis. J. Agric. Food Chem. 45, 3821-3825.

SIEVWRIGHT, C.A. and SHIPE, W.F. 1986. Effect of storage conditions and chemical treatments on firmness, in-vitro protein digestibility, condensed tannins, phyticacid and divalent cations of cooked black beans (Phaseolus vulgaris). J. Food Sci. 51, 982-987.

SZAKÁCS, G. and STANKOVICS, L. 1983. Debittering of lupine seed by lactic acid fermentation. In Symposium on Microbiology 1983 (J. Holló, ed.) pp. 273-274, Hungarian Academy of Sciences, Budapest, Hungary.
TORRES-TELLO, F., NAGATA, A. and DREIFUSS-SPIEGEL, W. 1980. Métodos de eliminación de alcaloides en la semilla de Lupinus mutabilis, Sweet [Methods of eliminating alkaloids from the seeds of Lupinus mutabilis Sweet]. Arch. Latinoam. Nutr. 30, 200-209.

TOUCHE, A., COURTOIS, D., FRECHE, J.P., BROMET, N., DJEDAIINI-PILARD, F., PERLY, B., GUILLAUMET, G. and ROLLIN, P. 1997. A general NMR approach for the structural determination of alkaloids: application to $3-\beta$ hydroxylupanine. J. Agric. Food Chem. 45, 2148-2152.

VAN BOEKEL, M.A.J.S. 2009. Kinetic Modeling of Reactions in Foods, CRC/Taylor \& Francis, Boca Raton, FL.

VILLACRÉS, E., CAICEDO, C. and PERALTA, E. 2000. Diagnóstico del procesamiento artesanal, comercialización y consumo del chocho. In Zonificación Potencial, Sistemas de Producción y Procesamiento Artesanal del Chocho (Lupinus mutabilis Sweed) en Ecuador (C. Caicedo and E. Peralta, eds.) pp. 24-41, INIAP-FUNDACIT, Quito, Ecuador. In Chocho o lupino producción, fitonutrición, enfermedades y plagas, zonificación, mercado y postcosecha, agroindustria, guía del cultivo de chocho y costos de producción, (E. Peralta, ed.) Published as CD by INIAP-FUNDACIT, Quito, Ecuador, Quito, Ecuador.

VILLACRÉS, E., PERALTA, E. and ALVAREZ, M. 2003. Chochos en su punto, 118. In Chochos. Recetarios. Disfrute Cocinando con Chochos, (E. Peralta, ed.) Published as CD by INIAP-FUNDACIT, Quito, Ecuador, 55 pp.

VON BAER, D., REIMERDES, E.H. and FELDHEIM, W. 1979. Methoden zur bestimmung der chinolizidinalkaloide in Lupinus mutabilis. Z. Lebensm. Unters. U. Forsch. 169, 27-31.

WALSTRA, P. 2003. Physical Chemistry of Foods, Marcel Dekker, Inc, New York. 807 pp.

ZDUŃCZYK, Z., JUŚKIEWICZ, J., FLIS, M. and FREJNAGEL, S. 1996. The chemical composition and nutritive value of low-alkaloid varieties of white lupin 2 oligosaccharides, phytates, fatty acids and biological value of protein. J. Anim. Feed Sci. 5, 73-82. 